\title{
Protozoan size influences algal pigment degradation during grazing
}

\author{
Suzanne L. Strom*, T. Aaron Morello**, Kelley J. Bright \\ Shannon Point Marine Center, Western Washington University, 1900 Shannon Point Rd, Anacortes, Washington 98221, USA
}

\begin{abstract}
Degradation of algal pigments during grazing by planktonic protozoa was examined using batch cultures of 6 protozoan species ( 3 ciliates, 3 heterotrophic dinoflagellates). Pigment losses due to grazer activity were compared with algal cell losses to determine pigment degradation efficiencies. Chlorophylls $a$ and $c$ were degraded (i.e. converted to phaeopigments or to colorless compounds) with high efficiencies ( $\geq 94 \%$ ) in nearly all experiments. Degradation efficiencies for carotenoids were variable (reaching maxima of 38 to $103 \%$ ), indicating that chlorophylls are intrinsically more labile than carotenoids in the presence of grazers. Algal species and carotenoid identity appeared to have little effect on degradation efficiency. Rather, grazers were the main source of variability, with small $(<25 \mu \mathrm{m}$ ) protozoa (Amphidinium sp., Gymnodinium sp., Uronema sp.) able to degrade carotenoids more efficiently than large $(>80 \mu \mathrm{m})$ protozod (Favella sp., Strombidinopsis acuminatum, Noctiluca scintillans). Regardless of grazer size, little algal pigment was found in the dissolved $(<0.7 \mu \mathrm{m})$ phase, demonstrating that pigment removed from the particulate phase was truly degraded and not simply repackaged as colloidal (or smaller) material. Degradation of carotenoids varied during experiments, increasing as much as 5 -fold over time. Such increases suggested that, during the later stages of incubations, protozoa were reingesting pigmented waste particles or digesting pigments more extensively in response to decreasing food concentrations. These data indicate that small protozoa degrade ingested algal carotenoids and, by extension, ingested organic matter more extensively than large protozoa. Microzooplankton size structure may have a strong influence on the efficiency of organic matter recycling in microbially dominated planktonic systems.
\end{abstract}

KEY WORDS: Chlorophyll · Carotenoid · Digestion - Ciliate - Dinoflagellate $\cdot$ Microzooplankton

\section{INTRODUCTION}

Planktonic protozoa are major consumers of phytoplankton in many ocean regions (Sherr \& Sherr 1993). This includes both the open ocean, where the phytoplankton community often is dominated by very small cells, and coastal waters, where the diverse feeding strategies of protozoa allow them access to even the larger phytoplanktonic species (e.g Neuer 1992, Landry et al. 1995, Strom \& Strom 1996, Verity et al. 1996). Given the importance of protozoa as herbivores, protozoan food vacuoles must be a major site of

\footnotetext{
•E-mail: stroms@cc.wwu.edu

-Present address: School of Oceanography, Box 357940, University of Washington, Seattle, Washington 98195, USA
}

organic matter transformation in ocean waters. Furthermore, the efficiency and variability of protozoan digestion should strongly influence the availability of resources to bacteria, planktonic detritivores, and consumers of protozoa. Little is known, however, about the regulation and biogeochemical consequences of protozoan digestion.

As a means of examining organic matter degradation by protozoa, we measured the disappearance of algal pigments (i.e. removal of the parent pigment molecule) during grazing by planktonic ciliates and heterotrophic dinoflagellates. Degradation of algal pigments by protozoa gives insight into factors influencing digestive efficiency. Furthermore, disappearance of algal pigment often is used as an indicator of algal cell removal during microzooplankton grazing experi- 
ments, either on a whole-community level, via chlorophyll a (chl a), or on a taxon-specific level, via algal carotenoids (e.g. Landry \& Hassett 1982, Burkill et al. 1987, Strom \& Welschmeyer 1991, Verity et al. 1996\}. Only a few tests comparing algal cell and carotenoid loss have been reported, however, with those tests exclusively employing the heterotrophic dinoflagellate Oxyrrhis marina (Klein et al. 1986, Barlow et al. 1988, Waterhouse \& Welschmeyer 1995).

In this study, protozoa from 2 dominant planktonic groups-ciliates and heterotrophic dinoflagellateswere isolated from coastal seawater, grown in batch culture, and fed algal diets that supported high growth rates. Protozoan growth, grazing, and selective feeding during these experiments are described elsewhere (Strom \& Loukos 1998, Strom \& Morello 1998). Here we report that, while algal chlorophylls were consistently degraded with a high efficiency, degradation of algal carotenoids by grazers was variable. The largest sources of variability were time (probably a proxy for other changing conditions in these batch culture experiments) and grazer size, with small protozoa exhibiting the highest degradation efficlencies.

\section{MATERIALS AND METHODS}

Experimental procedures are described in detail in Strom \& Morello (1998). Briefly, 6 species of protozoan grazers ( 3 ciliates, 3 heterotrophic dinoflagellates) isolated from coastal Washington and Oregon (USA) waters were tested in simple growth assays to determine which phytoplankton species supported the highest protozoan growth rates. A range of phytoplankton species (Strom \& Morello 1998) were tested both singly and in pairs. For the experiments described below, protozoa were fed paired algal species only if the pair supported higher growth rates than any single species.

The selected phytoplankton species were grown to late exponential phase in stock cultures; each experiment was then initiated by adding phytoplankton to $0.2 \mu \mathrm{m}$ filtered seawater in each of 6 or 8 replicate 231 polycarbonate carboys (Table 1). Protozoan grazers were added to half ( 3 or 4 ) of these carboys at initial concentrations of 0.1 to 107 cells $\mathrm{ml}^{-1}$ (Table 1 ). Initial volume in carboys was 11 to $23 \mathrm{l}$, while initial total algal concentration (Table 1) was 210 to 29580 cells $\mathrm{ml}^{-1}$ (equivalent to 190 to $390 \mu \mathrm{g} \mathrm{C} \mathrm{l}^{-1}$ ). Carboys were incubated at $13^{\circ} \mathrm{C}$ in dim light $\left(\leq 1 \mu \mathrm{mol}\right.$ photons $\mathrm{m}^{-2}$ $\mathrm{s}^{-1}$ ) with a $12 \mathrm{~h}$ light: $12 \mathrm{~h}$ dark cycle. Subsamples for determination of algal and grazer abundance and pigment concentration were withdrawn initially and every 12 to 24 h for 6 to 10 d, uniiil alyal siucks were nearly exhausted in grazer-containing carboys. Algal abundance was determined by epifluorescence microscopy and protozoan grazer abundance by inverted microscopy. Cell dimensions were measured on acid Lugol's-preserved samples using image analysis (Bioscan Optimas software). Algal biomass was estimated from algal abundances and cell volumes (Montagnes et al. 1994).

Table 1. Grazer and prey identities, sizes and concentrations for protozoan grazing experiments. Grazer $(n=50)$ and algal $(n=40)$ cell dimensions obtained from mid-experiment samples preserved in acid Lugol's ( $5 \%$ final conc.). Dimensions ( $\mu$ m, $\mathrm{l}=$ length, $\mathrm{w}=$ width) measured using a Bioscan Optimas image analysis system, cell volumes $\left(\mathrm{\mu m}^{3}\right)$ calculated from cell dimensions using standard geometric formulae. Taxon: $\mathrm{c}=$ ciliate, $\mathrm{d}=$ heterotrophic dinoflagellate

\begin{tabular}{|c|c|c|c|c|c|c|c|c|}
\hline Expt & Grazer & Taxon & $\begin{array}{c}\text { Cell vol. } \\
(1 \times w)\end{array}$ & $\begin{array}{c}\text { Initial } \\
\text { (cells } \mathrm{ml}^{-1} \text { ) }\end{array}$ & Algal prey & Cell vol. & \multicolumn{2}{|c|}{ (cells $\mathrm{ml}^{-1}$ ) } \\
\hline 1 & Favella sp. & c & $\begin{array}{l}112660^{2} \\
(81 \times 52)\end{array}$ & 0.09 & $\begin{array}{l}\text { Gymnodinium simplex } \\
\text { Pyrenomonas salinab }\end{array}$ & $\begin{array}{r}265 \\
93\end{array}$ & $\begin{array}{l}4220 \\
9040\end{array}$ & $\begin{array}{l}150 \\
230\end{array}$ \\
\hline 2 & $\begin{array}{l}\text { Strombidinopsis } \\
\text { acuminatum }\end{array}$ & c & $\begin{array}{c}70860 \\
(109 \times 50)\end{array}$ & 0.37 & $\begin{array}{l}\text { Prorocentrum minimum } \\
\text { Pyrenomonas salina }\end{array}$ & $\begin{array}{l}337^{\circ} \\
111\end{array}$ & $\begin{array}{l}1050 \\
9370\end{array}$ & $\begin{array}{r}0 \\
260\end{array}$ \\
\hline 3 & Amphidinium sp. & d & $\begin{array}{c}2750 \\
(22 \times 16)\end{array}$ & 15 & $\begin{array}{l}\text { Isochrysis galbana } \\
\text { Pyrenomonas salina }\end{array}$ & $\begin{array}{r}28 \\
125\end{array}$ & $\begin{array}{r}20590 \\
8990\end{array}$ & $\begin{array}{r}5590 \\
720\end{array}$ \\
\hline 4 & Uronema sp. & c & $\begin{array}{r}790 \\
(14 \times 11)\end{array}$ & 20 & $\begin{array}{l}\text { Isochrysis galbana } \\
\text { Pyrenomonas salina }\end{array}$ & $\begin{array}{r}25 \\
122\end{array}$ & $\begin{array}{l}13640 \\
12040\end{array}$ & $\begin{array}{r}540 \\
70\end{array}$ \\
\hline 5 & Gymnodinium sp. & $\mathrm{d}$ & $\begin{array}{r}440 \\
(11 \times 9)\end{array}$ & 1.07 & Isochrysis galbana & 29 & 40630 & 250 \\
\hline 6 & Noctiluca scintillans & $\mathrm{d}$ & $\begin{array}{c}9211630 \\
(271 \times 255)\end{array}$ & 0.50 & prorocentrum micans & 8703 & 214 & 1 \\
\hline $\begin{array}{l}{ }^{a} \text { Volu } \\
{ }^{b} \text { Equi } \\
\text { cVolu }\end{array}$ & $\begin{array}{l}\text { me of tintinnid cell; lo } \\
\text { ivalent to Rhodomonas } \\
\text { me of cell contents; th }\end{array}$ & $\begin{array}{l}\text { rica vol } \\
\text { s salina } \\
\text { ieca vol }\end{array}$ & $\begin{array}{l}\text { e averaged } 5 \\
\text { arondsen } 199 \\
\text { e averaged } 1\end{array}$ & $\begin{array}{l}380 \mu \mathrm{m}^{3} \\
5 \mu \mathrm{m}^{3}\end{array}$ & & & & \\
\hline
\end{tabular}


Samples for HPLC analysis of algal pigments were collected on $25 \mathrm{~mm}$ Whatman GF/F filters and immediately frozen in liquid $\mathrm{N}_{2}$. All filtrations (including disk extractions, see below) were done in dim light. Filters were extracted (dark, $-20^{\circ} \mathrm{C}$ ) for approximately $24 \mathrm{~h}$ in small volumes of $90 \%$ acetone. Ethyl $\beta$-apo-8'carotenoate was used as an internal standard. Pigments were analyzed on a Hewlett Packard model $1050 \mathrm{~A}$ system (absorbance detection at $436 \mathrm{~nm}$ ) with an added Waters $420 \mathrm{C}$ fluorescence detector [excitation range 350 to $500 \mathrm{~nm}$ (425 $\mathrm{nm}$ max.), emission range $>650 \mathrm{~nm}$ ] and Shimadzu SIL/SCL6B autosampler. An in-line diode array spectrophotometer (Hewlett Packard 8452A) was used periodically for peak identification

Pigment separation utilized a Rainin C-18 Dynamax column ( $4.6 \mathrm{~mm} \times 15 \mathrm{~cm}, 5 \mu \mathrm{m}$ particle size). The solvent gradient (Table 2) was a modification of the methanol-acetone system of Mantoura \& Llewellyn (1983); in preliminary tests we found that the acetonitrile-ethyl acetate system of Wright et al. (1991) led to unacceptable broadening of phaeophorbide peaks. The HPLC was standardized with pure algal pigments as described by Mantoura \& Repeta (1997). Peak integration was by Macintegrator 1.4 software. In a few cases, carotenoid pigments either were undetectable at these sample sizes (e.g. $\beta$-carotene in Expt 2) or coeluted with a pigment degradation product and could not be quantified (e.g. diadinoxanthin in Expt 2, $\alpha$ carotene in Expt 3)

Degradation efficiencies, the percentage of ingested pigment that was degraded, were calculated for each major algal pigment in each experiment (with exceptions above). The term 'pigment degradation' has been used variously by different authors. Here pigment degradation is defined as any alteration of the parent pigment molecule. The fate of that molecule, whether it be alteration into an identifiable compound (e.g. phaeopigment) or conversion to colorless products, is not reflected in our degradation efficiency values.

Degradation efficiencies (DE) were calculated for each sampling time $t$ as follows:

$$
\mathrm{DE}=\frac{P_{0}-P_{l}}{P_{0}-P_{\text {pred }}} 100
$$

where $P_{0}=$ pigment concentration at time 0 and $P_{t}=$ pigment concentration at time $t$ in grazer-containing carboys. $P_{\text {pred, }}$ the predicted pigment concentration, was calculated from the algal cell density in the grazercontaining carboys and the carboy-averaged pigment per cell at time $t$ from the control (algae-only) carboys. Degradation efficiency is thus the actual amount of algal pigment removed (from the beginning of an experiment to a given time point) as a percentage of the theoretical amount removed had all pigment in
Table 2. Composition (\%) of linear solvent gradients used for HPLC separation of algal pigments. Solvent A: $75 \%$ methanol: $25 \% 0.05 \mathrm{M}$ ammonium acetate (pH 7.2). Solvent B: methanol. Solvent $\mathrm{C}$ : acetone. Flow rate $=1 \mathrm{ml} \mathrm{mir}^{-1}$

\begin{tabular}{|cccc|}
\hline $\begin{array}{c}\text { Time } \\
(\mathrm{min})\end{array}$ & $\mathrm{A}$ & $\begin{array}{c}\text { Solvent } \\
\mathrm{B}\end{array}$ & $\mathrm{C}$ \\
\hline 0 & 100 & & \\
10 & & 85 & 15 \\
17 & & 70 & 30 \\
22 & & 20 & 80 \\
27 & & 20 & 80 \\
29 & 100 & 85 & 15 \\
32 & 100 & & \\
36 & & & \\
\hline
\end{tabular}

every ingested cell been altered. Calculations were based on pigment in the particulate $(>0.7 \mu \mathrm{m})$ fraction, such that a degradation efficiency of $100 \%$ represents removal of all ingested algal pigment from the particulate fraction. Degradation efficiencies could not be estimated accurately for early experiment time points when changes in cell and pigment concentration were small; therefore only data from later time points (the last several days) are presented.

We feel confident that our data were not biased by differences in cell pigment content (due to, for example, differences in nutrient availability) between control and grazer-containing carboys. Initial nutrient levels in filtered seawater were relatively high (nitrate $\geq$ $10 \mu \mathrm{M}$, ammonium $\geq 1 \mu \mathrm{M}$, phosphate $\geq 1.5 \mu \mathrm{M}$ ) and carotenoidichl a ratios in control carboys changed little $(\leq 15 \%)$ during the incubations.

Samples for dissolved pigment analysis were collected at a single (usually the final) time point for each of 4 grazing experiments (see arrows on Fig. 1). Subsamples $(600$ or $1200 \mathrm{ml}$, depending on the experiment) from both control and grazer-containing carboys were filtered through GF/F filters (effective pore size $0.7 \mu \mathrm{m}$ ) and the filtrate collected in polycarbonate bottles. Methanol (0.5\% final conc.) was added to filtrate, which was then passed through Empore (3M) $25 \mathrm{~mm}$ C18 extraction disks. Disks had been preconditioned with acetone, methanol, and Nanopure water. After all filtrate had passed through disks, they were placed in small volumes $(<2 \mathrm{ml})$ of acetone and allowed to extract for approximately $24 \mathrm{~h}$ (dark, $-20^{\circ} \mathrm{C}$ ). Disks were then removed from the acetone and the acetone was frozen in liquid $\mathrm{N}_{2}$ until HPLC analysis (as described above). During one experiment, filtrate was spiked with ethyl $\beta$-apo-8'-carotenoate in acetone $(0.26 \mathrm{ml}$ into $1200 \mathrm{ml}$ filtrate) as a test of recovery. Added carotenoate was recovered with an average efficiency of $42 \%(S D=9 \%, n=9)$; this value was used to adjust measured dissolved pigment concentrations. 
Table 3. Average maximum degradation efficiencies $(\%)$ for chlorophylls $c$ and a and combined carotenoids, with SE in parentheses. n: no. of carotenoid pigments averaged per experiment

\begin{tabular}{|lrrrr}
\hline Grazer & \multicolumn{1}{c}{ Chlc } & \multicolumn{1}{c}{ Chl $\underline{\text { Carotenoids }}$} & $\mathrm{n}$ \\
\hline Favella sp. & $76.2(1.9)$ & $87.3(1.1)$ & $65.5(5.3)$ & 5 \\
Strombidinopsis acuminatum & $102.3(2.7)$ & $101.4(0.4)$ & $48.0(5.7)$ & 3 \\
Amphidinium sp. & $99.5(3.3)$ & $101.7(4.8)$ & $101.2(3.0)$ & 4 \\
Uronema sp. & $98.7(1.0)$ & $97.6(1.1)$ & $93.1(1.8)$ & 5 \\
Gymnodinium sp. & $100.8(0.2)$ & $98.9(0.6)$ & $102.8(0.7)$ & 3 \\
Noctiluca scintillans & $94.0(0.6)$ & $94.1(0.4)$ & $69.6(4.7)$ & 3 \\
\hline
\end{tabular}
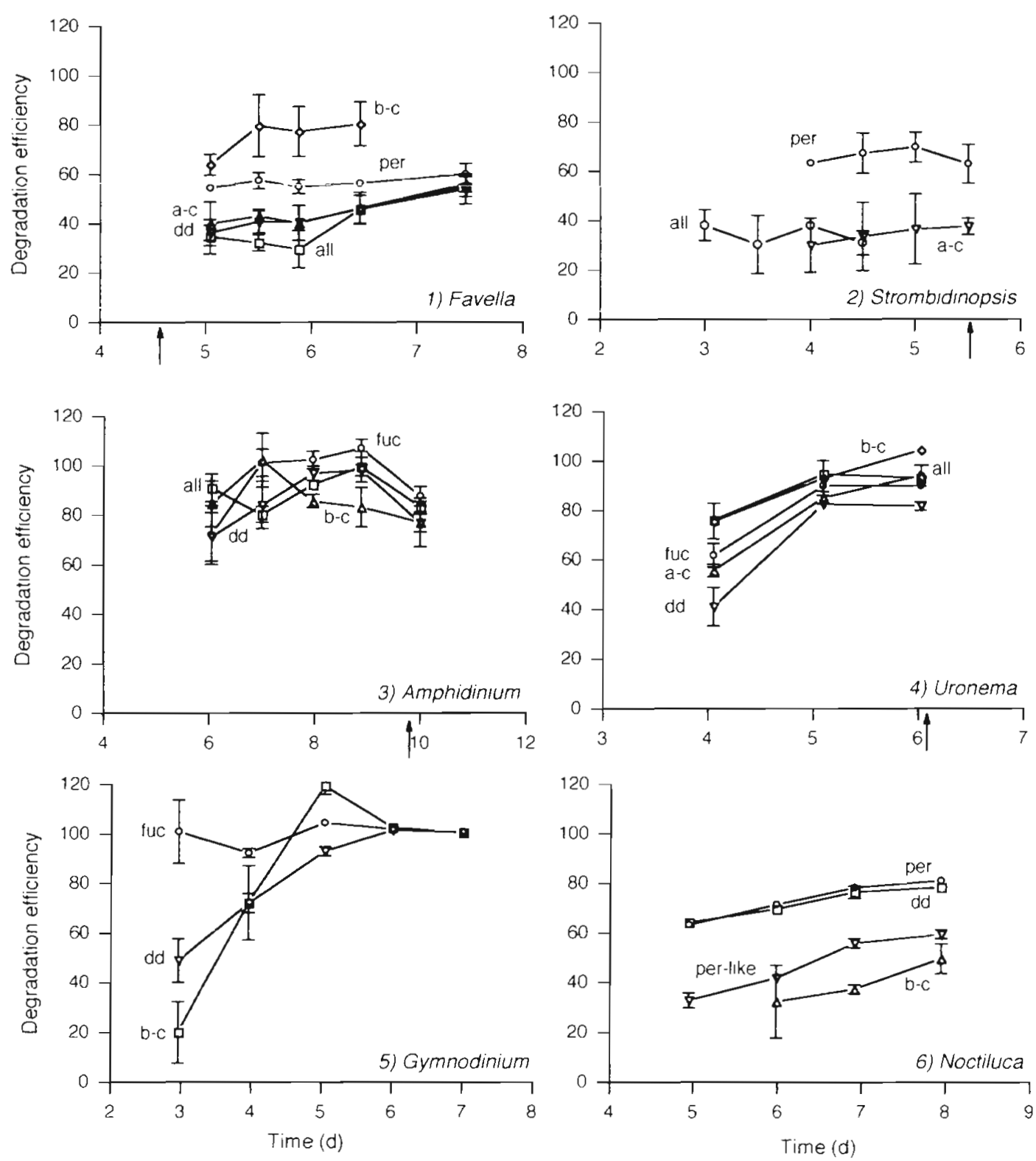

Fig 1. Degradation efficiencies (avg $\pm 1 \mathrm{SE}$ ) for carotenoids during the last several days of protozoan grazing experiments. Efficiencies at each time point calculated using Eq. (1). Experiment number and grazer genus indicated on each plot (see Table 1 for full species names). Arrows ( $x$-axis, Expts $1-4)$ indicate times when filtrate was collected for dissolved pigment analysis b-c: $\beta$-carotene, a-c: $\alpha$-carotene; per: peridinin; per-Jike: peridinin-like; dd: diadinoxanthin; all: alloxanthin; fuc: fucoxanthin 

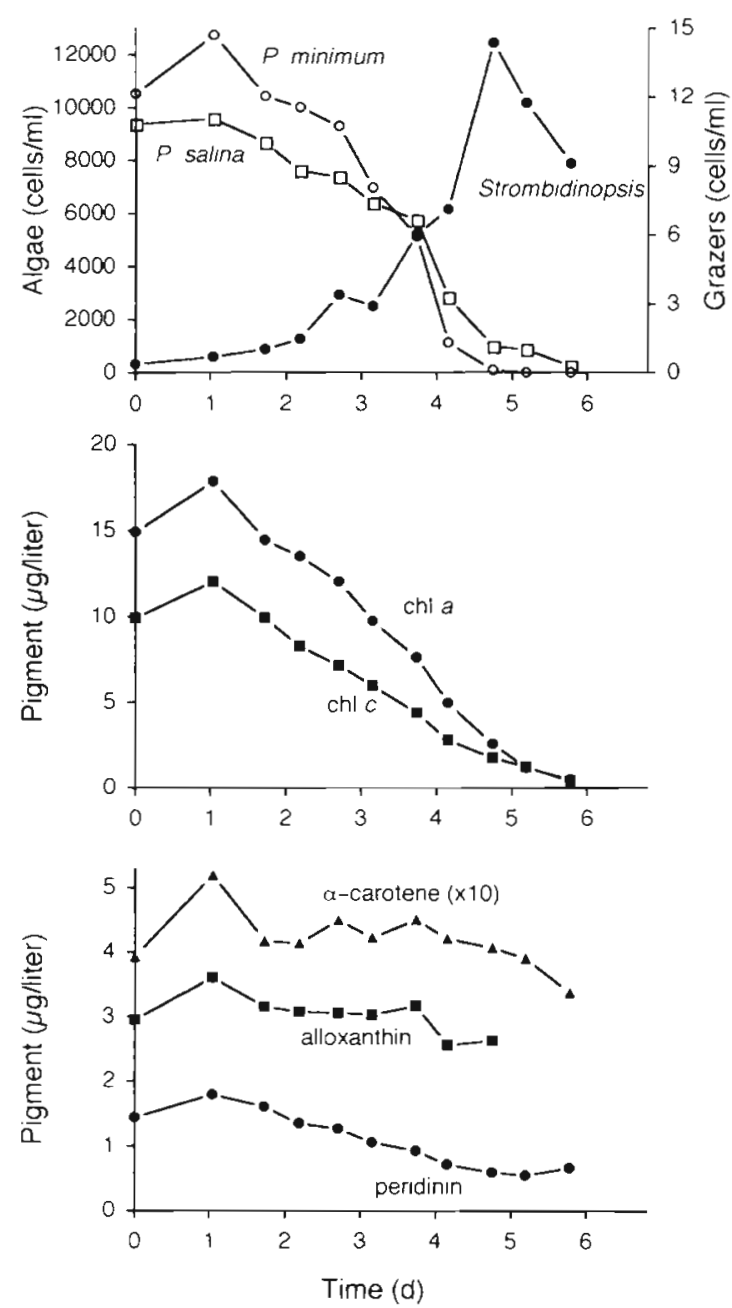

Fig. 2. Time course of algal, grazer and pigment concentration in grazer-containing carboys during Expt 2 (see Table 1 for full species names). Symbols represent averages of 3 replicate carboys

\section{RESULTS}

Chls $a$ and $c$ were degraded with a high efficiency in all experiments. Maximum degradation efficiencies for chlorophylls were $\geq 94 \%$ in all experiments except Expt 1, in which the tintinnid Favella sp. was the grazer (Table 3). Considering all grazer taxa, there was no significant difference between degradation efficiencies for chl a (avg 97\%, SE 1\%) and chl C (avg $94 \%$, SE $2 \%$ ) (paired $t$-test, $\mathrm{p}=0.19$ ).

In contrast to the chlorophylls, carotenoid pigments showed widely varying degradation efficiencies, with maxima ranging from 38 to $103 \%$ (Fig. 1). In most experiments there was a substantial amount of carotenoid pigment left in the carboys at the end of the incubation, although nearly all algal cells had been removed (Fig. 2). Furthermore, while degradation effi-

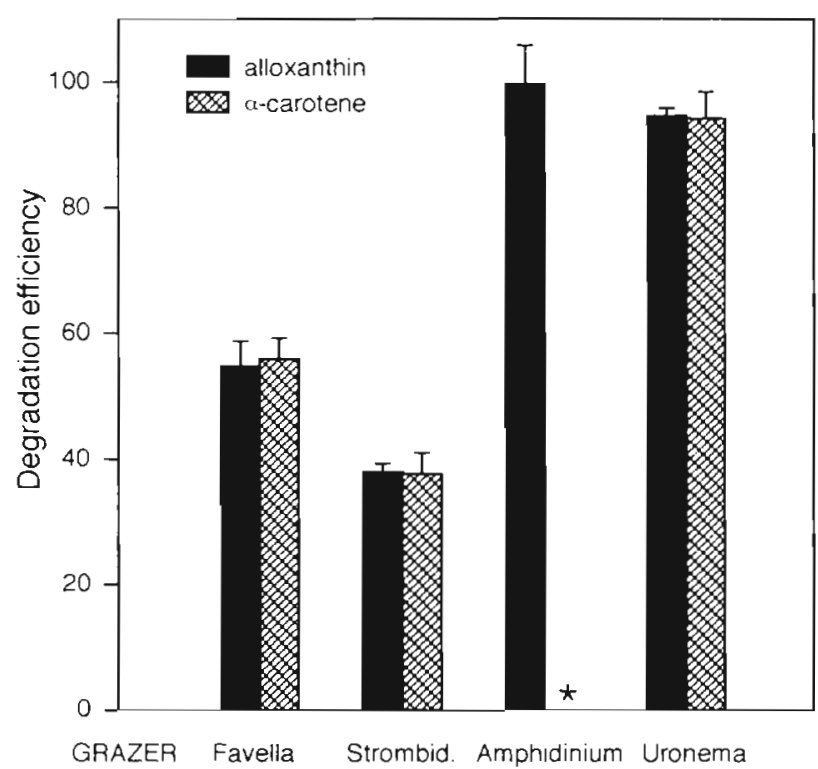

Fig. 3. Maximum degradation efficiencies (avg $+1 \mathrm{SE}$ ) for carotenoids during experiments involving the algae Pyrenomonas salina. $(\star) \alpha$-carotene not quantified in Expt 3 due to coelution with phaeophytin a. (See Table 1 for full species names)

ciencies for chlorophylls remained constant over time (data not shown), efficiencies for carotenoids increased over time in most experiments (Fig. 1).

Data were examined to determine the source of variability in carotenoid degradation efficiency. Because the experiment matrix was incomplete (i.e. not all algal and pigment types were fed to all grazers), statistical approaches were not employed. Degradation efficiencies for Pyrenomonas salina, the alga fed to the most grazer species (Table 1), suggest that neither algal nor pigment identity was a major determinant of degradation efficiency (Fig. 3). Maximum degradation efficiencies for $P$. salina pigments ranged from 38 to $100 \%$, with values for some individual pigments showing a similar range (e.g. alloxanthin 38 to $100 \%$; $\alpha$-carotene 38 to $94 \%$ ).

In contrast, carotenoid degradation efficiencies showed greater consistency when plotted as a function of grazer species (Fig. 4). Furthermore, small $(<25 \mu \mathrm{m}$ ) grazers (Amphidinium sp., Uronema sp., Gymnodinium sp.) consistently had higher and less variable degradation efficiencies than large (>80 $\mu \mathrm{m})$ grazers (Favella sp., Strombidinopsis acuminatum, Noctiluca scintillans). Average ( \pm SE) maximum efficiencies for small grazers were $98 \pm 1(\mathrm{n}=45)$, while maximum efficiencies for large grazers were $63 \pm 3(\mathrm{n}=36)$. There was no apparent effect of grazer taxon (ciliate vs dinoflagellate) on degradation efficiency (Fig. 4); similarly, all studied grazers feed by phagocytosis, so feeding mode could not account for observed differences. 


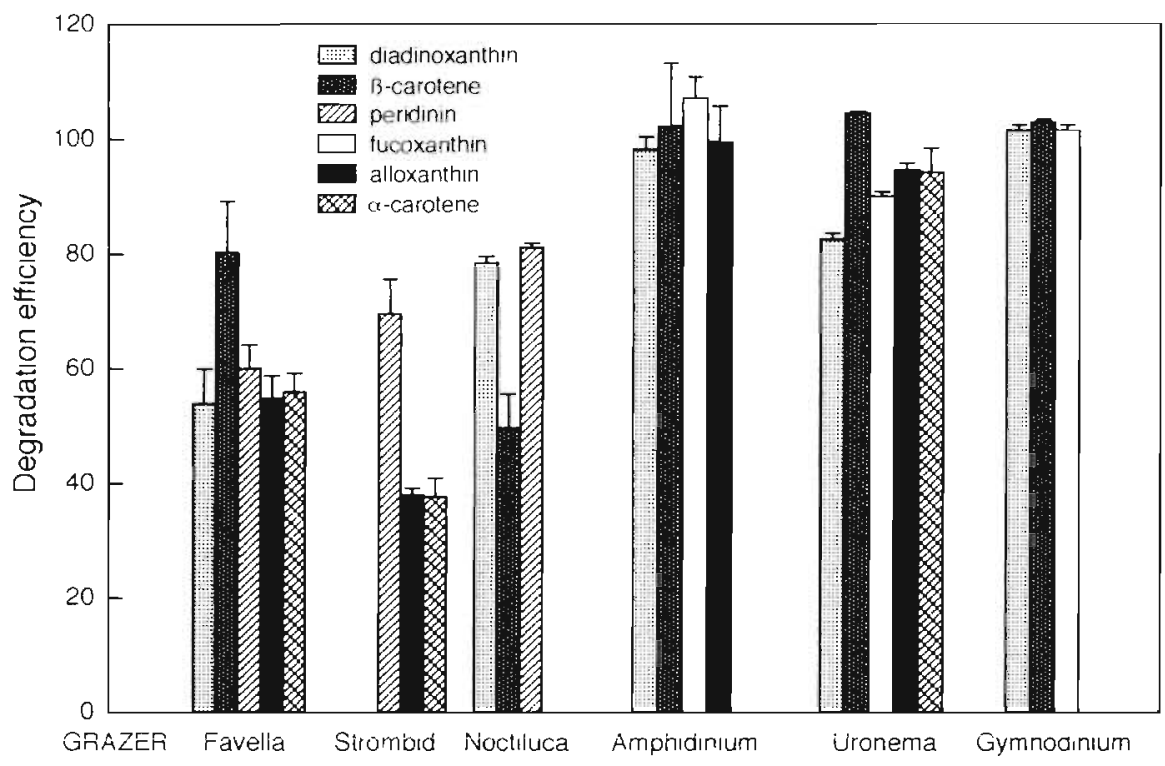

Fig. 4. Maximum degradation efficiencies (avg + 1 SE) for carotenoids during experiments with 6 protozoan grazer species (see Table 1 for full species names)

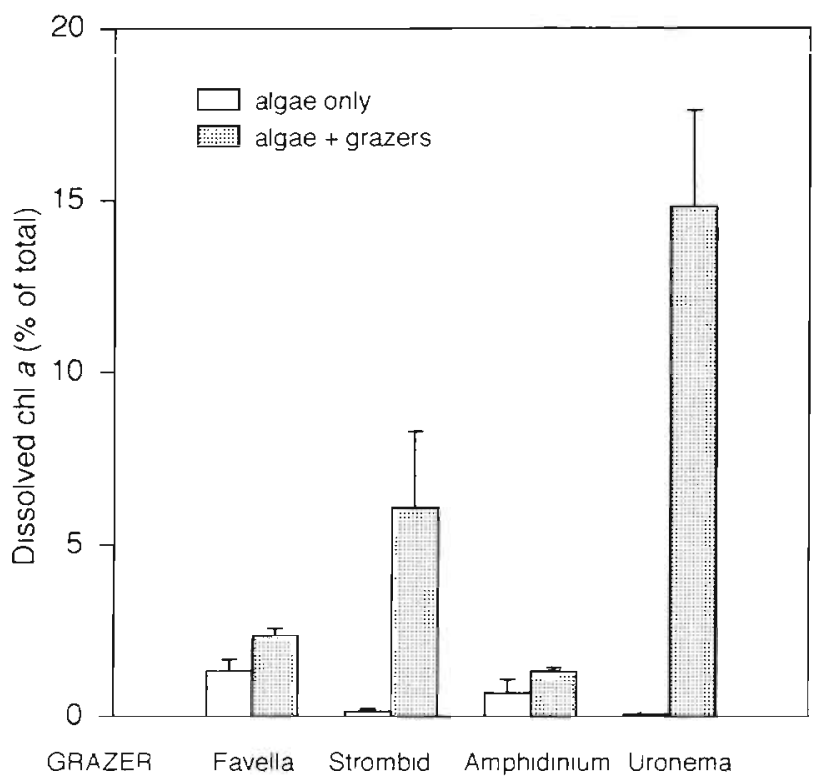

Fig 5 Dissolved chl a concentration (avg +1 SE) as a percentage of total (dissolved + particulate) chl a durng experments with 4 grazer species (see Table 1 for full species names). See Fig 1 ( $x$-axis arrows) for dissolved pigment sampling times
Chl $a$, phaeopigments derived from chls a and $c$, and xanthophylls were detected in filtrate from grazer-containing carboys. Although chlorophylls and their degradation products were readily matched with corresponding pigments in particulate samples, dissolved xanthophylls consistently eluted later (relative to the internal standard) than particulate xanthophylls. Further, chlorophylls and their derivatives could be quantıfied from fluorescence chromatograms, while the small xanthophyll absorbance peaks made quantifjcatıon uncertain and identification (via diode array spectroscopy) unrealistic.

Dissolved chl a comprised a relatively small percentage of total (dissolved + particulate) chl a (Fig. 5), but this percentage was always higher in grazer-containing carboys (range 1.3 to $14.8 \%$ ) than in control carboys (range 01 to $1.3 \%$ ). An example of pigment partitioning between the dissolved and particulate pools in grazer-containing carboys is presented using the data from the final time point ( $t=6 \mathrm{~d}$ ) of Expt 4 (Table 4 ). For this example, we assumed that the latest-eluting major xanthophyll was alloxanthin, as in particulate samples, although retention times did not agree. Thus the exam-

Table 4 Pigment concentrations and partitioning (grazer-containing carboys) at the final time point ( $t=6 \mathrm{~d}$ ) of Expt 4 . Pigment 'removed' represents pigment removed from the particulate phase by grazers over the entire experiment duration (corrected for control pigment changes) Identification of dissolved alloxanthin is uncertam, as xanthophylls in filtrate samples eluted later than xanthophylls in particulate samples (see text)

\begin{tabular}{|lcccc|}
\hline Pigment & Dissolved $\left(\mu \mathrm{I} \mathrm{I}^{-1}\right)$ & Particulate $\left(\mu \mathrm{g}^{-1}\right)$ & Dissolved (\% total) & Dissolved (\% removed) \\
\hline Alloxanthin & 004 & 011 & 277 & 3.3 \\
Chlorophyll $a$ & 014 & 082 & 144 & 1.6 \\
\hline
\end{tabular}


ple illustrates the maximum possible contribution of dissolved alloxanthin to the total alloxanthin pool. For both chl a and alloxanthin, dissolved pigment potentially contributed a modest amount of the total (14 to $28 \%$ ) at the end of Expt 4 . However, this dissolved pigment was only a small percentage (1.6 to $3.3 \%$ ) of the total pigment that had been removed from the particulate phase by grazers during the experiment. Similar or lower percentages characterized the other experiments. Therefore, although a variety of dissolved pigments was detected, the dissolved phase was not a significant repository of undegraded algal pigments during the grazing experiments.

\section{DISCUSSION}

Our most significant finding was that grazer size has an effect on carotenoid degradation efficiency. Small $(<25 \mu \mathrm{m})$ protozoa consistently degraded carotenoids with higher efficiencies than large $(>80 \mu \mathrm{m})$ protozoa during the later stages of the incubations. This difference between small and large protozoa does not appear to be due to food concentration differences, since final algal concentrations were similar and very low $\left(<10 \mu \mathrm{g} \mathrm{C}^{-1}\right)$ in all experiments except Expt 4 (Table 1; see also Fig. 1 in Strom \& Morello 1998). Furthermore, the low dissolved pigment concentrations that we measured do not support the idea that smaller protozoa are simply repackaging pigments into 'particles' (e.g. colloids, free chloroplasts) too small to be captured by glass fiber filters. Rather, these small grazers seem to be converting ingested carotenoids into other compounds more effectively than the larger grazer species.

Many physiological rates scale approximately to the $3 / 4$ power of body mass (Peters 1983). Thus smaller organisms typically have higher weight-specific rates of respiration, nutrient regeneration, and growth than large organisms (Fenchel \& Finlay 1983, Caron \& Goldman 1990), although many exceptions have been noted (e.g. Banse 1982). It is possible that our findings represent a similar allometric relationship between grazer cell mass and digestion efficiency. Allometric studies of physiological efficiencies are scarce relative to studies of physiological rates but do not, in general, support this hypothesis. Werner \& Hollibaugh (1993) found no relationship between body mass and assimilation efficiency for the Asian clam Potamocorbula amurensis, and Banse (1976), in a multiple-species comparison of benthic invertebrates, found no relationship between body mass and net growth efficiency. Finally, in complete opposition to our findings, carotenoid digestion efficiency was proposed to increase with body size in macrozooplankton, due to the longer gut transit times of the larger animals (Nelson 1989).

An alternative explanation for enhanced carotenoid degradation by small protozoa is that these grazers were better able to ingest and further degrade pigmented egesta (i.e. their own waste material) during the incubations. Several lines of evidence support this hypothesis. Pigmented particles with a dim red autofluorescence suggestive of phaeopigment were observed in experiments with Favella sp. and Noctiluca scintillans, and Stoecker (1984) reported that Favella produces substantial quantities of small waste particles. We were able to isolate pigmented egesta from $N$. scintillans cultures, which were subsequently used in a test of detritivory by the heterotrophic dinoflagellate Oxyrrhis marina (Strom unpubl. data). Autofluorescing waste particles were not observed in samples from experiments with small protozoan grazers. Furthermore, the largest temporal increases in degradation efficiency were observed in 2 experiments with small grazers (Fig. 1, Expts 4 and 5), as would be expected if these species were reingesting and further degrading pigmented wastes throughout the experiment. Increases in degradation efficiency in experiments with larger grazers (Fig. 1, Expts 1, 2 and 6) were slight or non-existent. Elevated concentrations of dissolved pigment in grazer-containing relative to control carboys (Fig. 5) also suggest that some amount of fine detrital material was produced during grazing. Finally, Strom (1993) used a grazing model to demonstrate that temporal patterns of phaeopigment production and disappearance in protozoan grazing experiments could be explained by reingestion and further breakdown of pigmented wastes.

Increased degradation efficiencies over time were observed in several of our experiments (Fig. 1). Numerous experiments with copepods feeding herbivorously have indicated that both feeding history and food concentration can affect chlorophyll and carotenoid loss during digestion (e.g. Landry et al. 1984, Downs \& Lorenzen 1985, Penry \& Frost 1991, Head \& Harris 1996). These investigators concluded that low food levels result in more extensive pigment loss, possibly due to increased gut passage times. Declining food levels toward the end of our incubations could have contributed to the increases in degradation efficiency seen over the later time intervals. It is unlikely that these increases were driven by changes in vacuole passage time, however, since vacuole passage times appear remarkably insensitive to food type, food concentration, or feeding history in planktonic protozoa (Sherr et al. 1988, Capriulo \& Degnan 1991, Dolan \& Coats 1991, Dolan \& Simek 1997). Thus any concentration-induced changes in digestion efficiency must involve alterations in vacuole chemical conditions and digestive physiology. Temporal increases in degrada- 
tion efficiency may also have been due to reingestion of pigmented waste material, as discussed above.

Chls a and $c$ showed greater lability than carotenoids in our experiments (Table 3), especially during earlier stages of the incubations. This is in broad agreement with other studies of pigment dynamics during grazing, which concluded that chlorophylls are intrinsically more labile than carotenoids (e.g. Abele-Oeschger \& Theede 1991, Head \& Harris 1992). More specifically, several studies of pigment degradation by the heterotrophic dinoflagellate Oxyrrhis marina (Klein et al. 1986, Barlow et al. 1988, Waterhouse \& Welschmeyer 1995) showed that chls $a$ and $c$ were consistently degraded more extensively than carotenoids.

Several authors have cautioned that incomplete breakdown of algal carotenoids by protozoa limits our ability to use carotenoid disappearance as a taxon-specific measure of herbivory in the field (Barlow et al. 1988, Waterhouse \& Welschmeyer 1995). This would be an obvious conclusion based on the $<100 \%$ degradation efficiencies that we observed. However, these simple experiments lack 2 key features of natural planktonic systems: light and detritivores. Nearly all Iaboratory experiments investigating pigment breakdown by protozoa (and many investigating larger zooplankton) have been conducted in dim light or darkness. Light is a powerful sensitizer of carotenoid degradation, however (Halliwell \& Gutteridge 1989), and may interact with digestion to accelerate the breakdown not only of pigments, but of other organic molecules in food vacuoles or detritus. In support of this, increased degradation of Rhodomonas sp. carotenoids (and chl c) in the light was observed during a laboratory study with the grazer Oxyrrhis marina (Klein et al. 1986). Similarly, it is likely that active detritivory will enhance carotenoid breakdown by subjecting pigments in grazer waste material to multiple digestion events. Studies that evaluate the importance of these 2 processes are needed.

Our data demonstrate that planktonic protozoa degrade algal carotenoids with a range of efficiencies. Large protozoan grazers were less effective than small grazers at degrading algal carotenoids, indicating fundamental differences in the abilities of these 2 groups to digest algal cells or to reingest pigmented wastes. Temporal changes in carotenoid degradation efficiencies also suggested reingestion of pigmented waste particles, changes in digestive physiology related to decreasing food concentration, or both. An important unanswered question is the extent to which degradation of carotenoids reflects degradation of bulk algal organic matter. To the extent that it does, the size composition of the micrograzer community appears to be a fundamental determinant of the efficiency with which organic matter will be recycled within microbially dominated planktonic systems.
Acknowledgements. The Uronema sp culture was graciously provided by B. and E. Sherr. We thank K. Thompson and J. Holmes for assistance with culture maintenance, and $W$. Arthurs for help with cell counts. HPLC pigment standards were provided by N. Welschmeyer. Comments of $\mathrm{G}$. MullerParker and the SPMC Plankton Group greatly improved the manuscript. This research was supported by the National Science Foundation (grant OCE 9301698) and the Department of Energy Ocean Margins Program (grant DE-FG0694ER61901).

\section{LITERATURE CITED}

Abele-Oeschger D, Theede H (1991) Digestion of algal pigments by the common periwinkle Littorina littorea L. (Gastropoda). J Exp Mar Biol Ecol 147:177-184

Banse K (1976) On weight dependence of net growth efficiency and specific respiration rates among field populations of invertebrates. Oecologia 38:111-126

Banse K (1982) Cell volumes, maximal growth rates of unicellular algae and ciliates, and the role of ciliates in the marine pelgial. Limnol Oceanogr 27:1059-1071

Barlow RG, Burkill PH, Mantoura RFC (1988) Grazing and degradation of algal pigments by marine protozoan Oxyrrhis marina. J Exp Mar Biol Ecol 119:119-129

Burkill PH, Mantoura RFC, Llewellyn CA, Owens NJP (1987) Microzooplankton grazing and selectivity of phytoplankton in coastal waters. Mar Biol 93:581-590

Capriulo GM, Degnan C (1991) Effect of food concentration on digestion and vacuole passage time in the heterotrichous marine ciliate Fabrea salina. Mar Biol 110:199-202

Caron DA, Goldman JC (1990) Protozoan nutrient regeneration. In: Capriulo GM (ed) Ecology of marine protozoa. Oxford University Press, New York, p 283-306

Dolan JR, Coats DW (1991) Preliminary prey digestion in a predacious estuarine ciliate, and the use of digestion data to estimate ingestion. Limnol Oceanogr 36:558-565

Dolan JR, Simek K (1997) Processing of ingested matter in Strombidium sulcatum, a marine ciliate (Oligotrichida). Limnol Oceanogr 42:393-397

Downs JN, Lorenzen CJ (1985) Carbon: pheopigment ratios of zooplankton fecal pellets as an index of herbivorous feeding. Limnol Oceanogr 30:1024-1036

Fenchel T, Finlay BJ (1983) Respiration rates in heterotrophic, free-living protozoa. Microb Ecol 9:99-122

Halliwell B, Gutteridge JMC (1989) Free radicals in biology and medicine. Clarendon Press, Oxford

Head EJH, Harris LR (1992) Chlorophyll and carotenoid. transformation and destruction by Calanus spp. grazing on diatoms. Mar Ecol Prog Ser 86:229-238

Head EJH, Harris LR (1996) Chlorophyll destruction by Calanus spp. grazing on phytoplankton: kinetıcs, effects of ingestion rate and feeding history, and a mechanistic interpretation. Mar Ecol Prog Ser 135:223-235

Klein B, Gieskes WWC, Kraay GG (1986) Digestion of chlorophylls and carotenoids by the marine protozoan Oxyrrhis marina studied by h.p.l.c. an.alysis of algal pigments. J Plankton Res 8:827-836

Landry MR, Constantinou J, Kirshtein. J (1995) Microzooplankton grazing in the central equatorial Pacific during February and August. 1992. Deep Sea Res II 42:657-671

Landry MR, Hassett RP (1982) Estimating the grazing impact of marine micro-zooplankton. Mar Biol 67:283-288

Landry MR, Hassett RP, Fagerness V, Downs J, Lorenzen CJ (1984) Effect of food acclimation on assimilation efficiency of Calanus pacificus. Limnol Oceanogr 29:361-364 
Mantoura RFC, Llewellyn CA (1983) The rapid determination of algal chlorophyll and carotenoid pigments and their breakdown products in natural waters by reverse-phase high-performance liquid chromatography. Anal Chim Acta 151:297-314

Mantoura RFC, Repeta DJ (1997) Calibration methods for HPLC. In: Jeffrey SW, Mantoura RFC, Wright SW (eds) Phytoplankton pigments in oceanography: guidelines to modern methods. UNESCO, Paris, p 407-428

Montagnes DJS, Berges J, Harrison PJ, Taylor JR (1994) Estimating carbon, nitrogen, protein, and chlorophyll a from volume in marine phytoplankton. Limnol Oceanogr 39 1044-1060

Nelson JR (1989) Phytoplankton pigments in macrozooplankton feces: variability in carotenoid alterations. Mar Ecol Prog Ser 52:129-144

Neuer S (1992) Role of protist grazing in the Oregon upwelling system. PhD thesis, Oregon State Univ, Corvallis

Penry DL, Frost BW (1991) Chlorophyll a degradation by Calanus pacificus: dependence on ingestion rate and digestive acclimation to food resources. Limnol Oceanogr 36:147-159

Peters RH (1983) The ecological implications of body size. Cambridge University Press, Cambridge

Sherr BF, Sherr EB, Rassoulzadegan F (1988) Rates of digestion of bacteria by marine phagotrophic protozoa: temperature dependence. Appl Environ Microbiol 54:1091-1095

Sherr EB, Sherr BF (1993) Bacterivory and herbivory: key roles of phagotrophic protists in pelagic food webs. Microb Ecol 28:223-235

Stoecker DK (1984) Particle production by planktonic ciliates. Limnol Oceanogr 29:930-940

Strom SL (1993) Production of pheopigments by marine pro-

Editorial responsibility: John Dolan (Contributing Editor),

Villefranche-sur-Mer, France tozoa: results of laboratory experiments analysed by HPLC. Deep Sea Res I 40:57-80

Strom SL, Loukos H (1998) Selective feeding by protozoa: model and experimental behaviors and their consequences for population stability. J Plankton Res (in press)

Strom SL, Morello TA (1998) Comparative growth rates and yields of ciliates and heterotrophic dinoflagellates. J Plankton Res (in press)

Strom SL, Strom MW (1996) Microplankton growth, grazing, and community composition in the northern Gulf of Mexico. Mar Ecol Prog Ser 130:229-240

Strom SL, Welschmeyer NA (1991) Pigment-specific rates of phytoplankton growth and microzooplankton grazing in the open subarctic Pacific Ocean. Limnol Oceanogr 36: $50--63$

Throndsen J (1993) The planktonic marine flagellates. In: Tomas CR (ed) Marine phytoplankton. Academic Press, San Diego, p 7-145

Verity PG, Stoecker DK, Sieracki ME, Nelson JR (1996) Microzooplankton grazing of primary production at $140^{\circ} \mathrm{W}$ in the equatorial Pacific. Deep Sea Res II 43: $1227-1256$

Waterhouse TY, Welschmeyer NA (1995) Taxon-specific analysis of microzooplankton grazing rates and phytoplankton growth rates. Limnol Oceanogr 40:827-834

Werner I, Hollibaugh JT (1993) Potamocorbula amurensis: comparison of clearance rates and assimilation efficiencies. Limnol Oceanogr 38:949-964

Wright SW, Jeffrey SW, Mantoura RFC, Llewellyn CA, Bjorland T, Repeta D, Welschmeyer N (1991) Improved HPLC method for the analysis of chlorophylls and carotenoids from marine phytoplankton. Mar Ecol Prog Ser 77 : $183-196$

Submitted: September 27, 1997; Accepted: January 19, 1998 Proofs received from author(s): March 27, 1998 